Available online on 15.03.2018 at http://jddtonline.info
Journal of Drug Delivery and Therapeutics
Open Access to Pharmaceutical and Medical Research
$\begin{gathered}\text { 2011-18, publisher and licensee JDDT, This is an Open Access article which permits unrestricted non- } \\ \text { commercial use, provided the original work is properly cited }\end{gathered}$

Open $\odot$ Access

Research Article

\title{
HYPOGLYCEMIC EFFECT OF POLYHERBAL FORMULATIONS IN ALLOXAN INDUCED DIABETIC MICE
}

\author{
Noopur Srivastava ${ }^{*}$, Awani K. Rai ${ }^{2}$ \\ ${ }^{1}$ Department of Pharmaceutical Sciences, Pranveer Singh Institute of Technology, Kanpur, Uttar Pradesh, India \\ ${ }^{2}$ Bhagwant University, Sikar Road, Ajmer, Rajasthan, India
}

\begin{abstract}
Objective: The present work was executed to evaluate the antidiabetic potency of herbal preparation which was the combination of wheat germ oil, fresh juice of Coriander sativum and Aloe vera gel in normal and alloxan-induced diabetic mice.

Methods: The serum glucose lowering activity of the herbal preparation (PH-1 in the ratio of 1:1:1 of wheat germ oil, fresh juice of C. sativum and Aloe vera) was studied in normal rats after oral administration at 1.0 and $2.0 \mathrm{ml} / \mathrm{kg}$ and herbal preparation (PH-1, PH-2 wheat germ oil, fresh juice of coriander sativum and Aloe vera gel in ratio of 2:2:1) and PH-3 (wheat germ oil, fresh juice of coriander sativum and Aloe vera gel in ratio of 1:2:2) on alloxan induced diabetic swiss albino mice, at doses of 1.0 and $2.0 \mathrm{ml} / \mathrm{kg}$. Blood samples were collected and analyzed for serum glucose at $0,1 / 2,1,2,4,8,12$ and $24 \mathrm{~h}$ in normal mice and at $0,1,3,7,15$ and 30 days in diabetic mice after drug administration by glucose oxidase/peroxidase method. The data were compared statistically by using one way ANOVA method followed by Dunnett multiple component test. Statical significance was set at $\mathrm{p}<0.05$.

Results: The herbal preparation $(1.0$ and $2.0 \mathrm{ml} / \mathrm{kg}$ ) produced significant $(\mathrm{p}<0.05)$ reduction in serum glucose level of both normal and diabetic mice and comparable with that of control and standard drug Glibenclamide.

Conclusion: The herbal preparation showed significant glucose lowering effect in normal and alloxan induced diabetic rats. This preparation is giving to be a promising antidiabetic preparation for masses and however, it requires further extensive studies in human beings.
\end{abstract}

Keywords: Antidiabetic potency, alloxan-induced diabetic rats, Aloe vera

Article Info: Received 09 Jan, 2018; Review Completed 23 Feb, 2018; Accepted 23 Feb, 2018; Available online 15 March, 2018

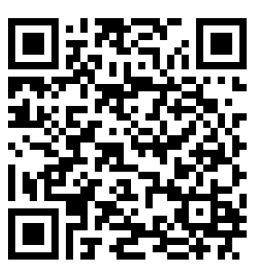

Cite this article as:

Srivastava N, Rai AK, Hypoglycemic effect of polyherbal formulations in alloxan induced diabetic mice, Journal of Drug Delivery and Therapeutics. 2018; 8(2):87-95

DOI: http://dx.doi.org/10.22270/jddt.v8i2.1670

*Address for Correspondence

Noopur Srivastava, Department of Pharmaceutical Sciences, Pranveer Singh Institute of Technology, Kanpur, Uttar Pradesh, India

\section{INTRODUCTION}

An inactive life, which involves lack of exercise \& poor calorie management, is one of the biggest contributors to the dreaded disease of diabetes ${ }^{1}$. India is facing an epidemic of diabetes. At present confirmed diabetes patients in India are 62 million, with another 30 million pre-diabetes group. By 2030, diabetes mellitus may afflict up to 79.4 million individuals in India ${ }^{2}$. Diabetes is not only a blood sugar problem, but brings along other complications as well. Diabetes can be treated by chemicals or drugs e.g. Pramlintide such as (SymlinPen 120, SymlinPen 60). But these drugs have various side effects also such as nausea ${ }^{3}$, vomiting, and watery diarrhea, headache and indigestion, mild allergic reactions with rash, itchiness and fever, problems with the kidneys, liver, lungs and pancreas. But due to their various side effects and consumer awareness, people are 
moving towards natural and safe means for treating the diseases.

Diabetes mellitus is one of the disease for which a satisfactory treatment is not available in modern allopathic system of medicine ${ }^{4}$. Therefore the search for an ideal drug for the treatment of diabetes containing and has been extended to herbs ${ }^{5}$. Antidiabetic drug from natural sources is preferred because of their less toxicity and a negligible side effect on to the body ${ }^{6},{ }^{7}$.

On perusal of literature survey, we found that the indigenous Indian system of medicine (Ayurveda) a mention was made on the good number of plants for the cure of diabetes, but the bio reactivity of single plant preparation is disappointing whereas combination of substance are likely to contain several bio reactive components which act together and elicit additive and synergistic effects which shows optimal therapeutic response that are not apparent when the single plant preparation are used. Therefore, we have selected three different plants product in our study, namely wheat germ oil, fresh juice of coriander sativum and Aloe vera. Aloe vera has been reported to have hypoglycemic activity. Hence, the specific objectives aimed in the present work are as follows:

- To ascertain the effectiveness of Polyherbal preparation for hypoglycemic activity in normal mice.

- To explore the effect of Polyherbal preparation for anti-diabetic activityin diabetic mice.

\section{MATERIALS AND METHODS}

\section{A. Materials}

The Polyherbal preparation which was used in the study has been prepared by using Wheat germ oil which has been provided by Bhaiji Attarwali perfumers (P) Ltd. Delhi,

Aloe vera gel collected from Aloe vera leaf which has been provided by Sree Siddaganga College of pharmacy botanical garden, Tumku rand fresh juice of Coriander leaves collected from Tumkur district and were authenticated by Prof. K. Siddappa, Head, Department of Botany, Sree Siddaganga Boy's College, Tumkur. Aloe vera leaves were washed properly to remove their. After washing, remove the skin of leaves, gels were separated and collected. Fresh juice of C. sativum obtained by crushing leaves in mortar and squeezed the crushed material by means of fine cloth to separate the juice and collected the fresh juice of leaves. Alloxan, sodium chloride, and acacia were obtained from S.D. Fine-Chem Limited, Mumbai. Glibenclamide tablet $(5 \mathrm{mg})$ was obtained from Nichols piramal India limited. Glucose estimation kit was supplied by Qualigens diagnostics.

\section{B. Development of Animal model for diabetes mellitus:}

\section{Animals}

For pharmacological experiments, swiss albino mice (28-32g) of either sex were used. The animals were obtained from animal house of Sree Siddaganga College of Pharmacy, Tumkur [Ref: 123/1999/CPCSEA dated 19/5/99]. Protocol of the experiments and animal usage were discussed in the Institutional Ethical Committee meeting and permission has been obtained to carry out the parameters selected for the study (See annexure-II) [Ref: SSCPT/ IAEC. Clear/ 41/ 2006-07 dated 25/11/06].

\section{Housing of Animal}

Animals were maintained in suitable nutritional and environmental condition throughout the experiment. They were provided with food, water ad libitum. The bedding material of the cages was changed every day. The animals were maintained under natural day and night cycle.

\section{Preparation of control and Test formulations.}

\section{Preparation of alloxan monohydrate $5 \%$ solution $^{8}$}

Alloxan monohydrate, $250 \mathrm{mg}$ was dissolved in $5.0 \mathrm{ml}$ of $0.9 \%$ sodium chloride to give $5.0 \%$ of Alloxan solution and injected immediately through the ip route within $5 \mathrm{~min}$ to avoid degradation.

\section{Glibenclamide Solution?}

Glibenclamide tablet of $5 \mathrm{mg}$ was dissolved in $83.33 \mathrm{ml}$ of distilled water to give $60 \mu \mathrm{g} / \mathrm{ml}$ solution. This solution was administered at a dose of $600 \mu \mathrm{g} / \mathrm{kg}$ body weight using clean and dry oral feeding needle for 30 days.

Preparation of herbal preparation (PH1, PH2 and PH3):

Herbal preparation-I (PH1): It consists of Wheat germ oil, fresh juice of Coriandrum sativum and Aloe vera in the ratio of $1: 1: 1$. Formulation was prepared by using acacia as a binding agent.

Take $2.0 \mathrm{ml}$ of wheat germ oil. Transfer it into a dry mortar. Add $500 \mathrm{mg}$ of gum acacia powder, mixed thoroughly by trituration. Add $1.0 \mathrm{ml}$ of Coriander juice at the time of continuous trituration until a light green product with clicking sound is produced. Primary emulsion was formed. Add Aloe vera gel $2.0 \mathrm{ml}$ with remaining $1.0 \mathrm{ml}$ of coriander juice separately. Add this solution at a time to primary emulsion with continuous and rapid trituration. The emulsion was used for study.

Herbal preparation-II (PH2): It consists of Wheat germ oil, fresh juice of Coriandrum sativum and Aloe vera in the ratio of $2: 2: 1$. Formulation was prepared by using acacia as a binding agent. 
Take $2.0 \mathrm{ml}$ of wheat germ oil. Transfer it into a dry mortar. Add $500 \mathrm{mg}$ of gum acacia powder, mixed thoroughly by trituration. Add $1.0 \mathrm{ml}$ of Coriander juice at the time of continuous trituration until a light green product with clicking sound is produced. Primary emulsion was formed. Add Aloe vera gel $1.0 \mathrm{ml}$ with remaining $1.0 \mathrm{ml}$ of coriander juice separately. Add this solution at a time to primary emulsion with continuous and rapid trituration. The emulsion was used for study.

Herbal preparation-III (PH3): It consists of Wheat germ oil, fresh juice of Coriandrum sativum and Aloe vera in the ratio of 1:2:2. Formulation was prepared by using acacia as a binding agent.

Take $1.0 \mathrm{ml}$ of wheat germ oil. Transfer it into a dry mortar. Add $250 \mathrm{mg}$ of gum acacia powder, mixed thoroughly by trituration. Add $1.0 \mathrm{ml}$ of Coriander juice at the time of continuous trituration until a light green product with clicking sound is produced. Primary emulsion was formed. Add Aloe vera gel $2.0 \mathrm{ml}$ with remaining $1.0 \mathrm{ml}$ of coriander juice separately. Add this solution at a time to primary emulsion with continuous and rapid trituration. The emulsion was used for study.

\section{Pharmacological evaluation}

\section{Experimental Animals:}

For pharmacological experiments, swiss albino mice $(28-32 \mathrm{~g})$ of either sex were used.

Induction of hyperglycemia with alloxan ${ }^{8,10}$ :

Swiss albino mice (28-32 g) were fasted for $14 \mathrm{~h}$ before challenging with single injection (i.p) of Alloxan monohydrate $5.0 \%$, freshly prepared and injected within $5 \mathrm{~min}$ of preparation to prevent degradation at a dose of $150 \mathrm{mg} / \mathrm{kg}$, i.p. After administration of alloxan the animals had free access to feed and water ad libidum. The blood glucose was measured $72 \mathrm{~h}$ of alloxanisation. After one week when the condition of diabetes was stabilized, the animals were fasted again for $14 \mathrm{~h}$ before blood collection withdrawal from retro orbital plexus. The swiss albino mice with fasting serum glucose level of above $200 \mathrm{mg} / \mathrm{dl}$ were considered diabetic and included in the study.

\section{Experimental design:}

The experimental setup consist of twelve groups, each group consist of five animals.

Group-I: Vehicle control received saline solution $(0.9 \%$ $\mathrm{NaCl})$.

Group-II: Normal mice received Glibenclamide as standard, single dose.

(Dose: $600 \mu \mathrm{g} / \mathrm{kg}$ ).

Group-III: Normal mice received PH-1, single dose.

(Dose: $1.0 \mathrm{ml} / \mathrm{kg}$ ).

Group-IV: Normal mice received PH-1, single dose.

(Dose: $2.0 \mathrm{ml} / \mathrm{kg}$ ).
Group-V: Alloxan induced mice received saline solution $(0.9 \% \mathrm{NaCl})$.

Group-VI: Diabetic mice given Glibenclamide as standard, orally once daily.

(Dose: $600 \mu \mathrm{g} / \mathrm{kg}$ ).

Group-VII: Diabetic mice given PH-1, orally once daily.

(Dose: $1.0 \mathrm{ml} / \mathrm{kg}$ ).

Group-VIII: Diabetic mice given PH-1, orally once daily. (Dose: $2.0 \mathrm{ml} / \mathrm{kg}$ ).

Group-IX: Diabetic mice given PH-2, orally once daily.

(Dose: $1.0 \mathrm{ml} / \mathrm{kg}$ )

Group-X: Diabetic mice given PH-2, orally once daily.

(Dose: $2.0 \mathrm{ml} / \mathrm{kg}$ ).

Group-XI: Diabetic rats given PH-3, orally once daily.

(Dose: $1.0 \mathrm{ml} / \mathrm{kg}$ ).

Group-XII: Diabetic rats given PH-3, orally once daily.

(Dose: $2.0 \mathrm{ml} / \mathrm{kg}$ ).

\section{Care of Diabetic Animals:}

Since diabetic animals drink large amount of fluid and produce large volume of urine, the bedding is changed frequently, usually every day, and, in some circumstances, more than once per day. Diabetic rats should have sufficient food and water; therefore only three diabetic mice have been housed per cage to avoid competition for feed and water.

\section{Blood sampling and blood glucose determination?:}

The swiss albino mice were placed on the working table, a mortar was inverted on it, and no gap was maintained in between mortar and the edge of the working platform. The tail was pulled out from the mortar's beak gap and the tail was depilated. The tail was cleaned with spirit and allowed to dry; tail vein was dilated by focusing a low voltage electric lamp at the tip of tail for few seconds. After the dilation of the vein the blood was drawn by tail vein method from mice (fasted for $14 \mathrm{~h}$ ) on different occasion, i.e., at $0,0.5,1,2,4,8,12$, and $24 \mathrm{~h}$ after oral administration of drug in groups I to IV, Where as in group V to XII at $0,1,3,7,15$ and 30 days. The blood samples were collected in centrifugation tube and add heparin $(0.2 \mathrm{ml}$ for $1.0 \mathrm{ml}$ blood $)$ as an anticoagulant. The plasma was obtained by centrifuging the blood samples at $3000 \mathrm{rpm}$ for $10 \mathrm{mins}$, decanting supernatant fluid into the clean, dry test tube. $10 \mu l$ of the plasma was collected and the blood glucose level was estimated by GOD/POD method.

\section{Estimation of Biochemical parameters ${ }^{9,11}$ :}

\section{Fasting Blood Plasma Glucose Estimation:}

Blood plasma glucose was estimated by the GOD/POD (Glucose oxidase and peroxidase) method using the 
GLUCOSE-GOD/POD kit (GSK Qualisystems; AR106).

\section{GOD /POD method}

The older methods were based on the reducing property of glucose. But these methods do not measure the true glucose because of interferences. Subsequently other chemical and enzymatic methods were developed to overcome this problem. The GOD/POD method is one such evolved method by Trinder in 1964. This method is precise, simple, and single stepped, rapid, safe and reliable. Hence, in the present study, we have adopted this method. Trinder's method (1964) utilizes two enzymes Glucose oxidase (GOD) and peroxidase (POD) along with the chromogen 4- amino antipyrine and phenol. This method is intended for in-vitro quantitative determination of glucose in serum/plasma and CSF. There was no interference due to the substances like creatinine, fructose, galactose, reduced glutathione, ascorbic acid and xylose. Hemoglobin or bilirubin up to $10 \mathrm{mg} \%$ does not affect the test.

\section{Principle}

Glucose is oxidized by the enzyme Glucose oxidase (GOD) to give D-gluconic acid and hydrogen peroxide. Glucose present in the blood is oxidized by the enzyme Glucose oxidase (GOD) to give D-gluconic acid and hydrogen peroxide. Hydrogen peroxide further reacts with 4-aminoantipyrine and phenol in presence of the enzyme peroxidase (POD) to undergo oxidation to produce a red colour quinoneimine dye.

The intensity of the colour produced is directly proportional to glucose concentration in the sample.

\section{GOD}

$\mathrm{D}-$ Glucose $+\mathrm{H} 2 \mathrm{O}+\mathrm{O} 2 \rightarrow \mathrm{D}-$ Gluconic acid $+\mathrm{H} 2 \mathrm{O} 2$

\section{POD}

$\mathrm{H} 2 \mathrm{O} 2+4-$ aminoantipyrine + phenol

$\rightarrow$ Quinoneiminedye $+\mathrm{H} 2 \mathrm{O}$

\section{Preparation of working reagent}

1 vial of enzyme powder was transferred to 1 bottle (100ml) of buffer solution and mixed gently to dissolve which is ready to use.

\section{Reagent storage and stability}

- All the reagents were stored at $2-8^{\circ} \mathrm{C}$, which is stable till the expiry date, reagents were not freeze.

$\rightarrow$ Capped reconstituted reagents are stable for 30 days at $2-8^{\circ} \mathrm{C}$.

- Reconstituted enzyme reagents when stored at 2$8^{\circ} \mathrm{C}$ develops a slight pink colour, however this does not affect the performance of the enzyme reagent.

- The reagents should not be used if caking is observed due to possible moisture penetration.

\section{Procedure}

Pipette out the solutions into clean, dry test tubes and labelled as blank (B), Standard (S), and test (T).Distilled water was considered as blank solution. To $1.0 \mathrm{ml}$ of the reagent, $10 \mu \mathrm{l}$ of standard glucose $(100 \mathrm{mg} / \mathrm{dl})$ was added and incubated for $15 \mathrm{~min}$ at $370^{\circ} \mathrm{C}$. This incubated mixture was aspirated and concentration of standard was calibrated to show a value of $100 \mathrm{mg} / \mathrm{dl}$. This process is duplicated to confirm the calibration value and was considered as correct if the value was within $5 \%$ of the original value.

The fasting blood plasma glucose was estimated by adding $10 \mu \mathrm{l}$ of the plasma sample to $1.0 \mathrm{ml}$ of the reagent, mixed well and incubated at $37^{0} \mathrm{C}$ for $15 \mathrm{~min}$. This incubated mixture was aspirated and absorbance recorded against a reagent blank at $510 \mathrm{~nm}$ using Photometer (GSK Qualisystems; AR106).

Table 1: General Procedure of GOD/POD for the estimation of glucose in plasma

\begin{tabular}{|l|l|l|l|l|}
\hline S. No & Content & Blank & Standard & Test \\
\hline 1 & Working reagent enzyme & $1.0 \mathrm{ml}$ & $1.0 \mathrm{ml}$ & $1.0 \mathrm{ml}$ \\
\hline 2 & Distilled water & $10 \mu \mathrm{l}$ & $10 \mu \mathrm{l}$ & $10 \mu \mathrm{l}$ \\
\hline 3 & Standard glucose & - & $10 \mu \mathrm{l}$ & - \\
\hline 4 & Serum (sample) & - & - & $10 \mu \mathrm{l}$ \\
\hline
\end{tabular}

\section{Calculation:}

The glucose concentration in $\mathrm{mg} \%$ was calculated using the formula.

Concentration of Sample $(\mathrm{mg} / \mathrm{dl})=\frac{\text { Absorbance of Sample }}{\text { Absorbance of Standard }} \times 100$

\section{E. Statistical Analysis:}

The values are expressed as mean \pm SEM. The data was analysed by using student's t-test using one way analysis of variance (ANOVA) followed by Dunnett multiple component test. Statistical significance was set at $\mathrm{P}<$ 0.05 . 


\section{RESULT AND DISCUSSION}

\section{Fasting Blood Plasma Glucose: X}

The fasting blood plasma glucose of the different groups of normal animals during the period of study is presented in graph 2, which shows that the mean $( \pm$ SEM) fasting plasma glucose values of the normal control group of mice was $96.4 \pm 1.364$ $\mathrm{mg} / \mathrm{dl}, 104.2 \pm 1.497 \mathrm{mg} / \mathrm{dl}, 102 \pm 1.342 \mathrm{mg} / \mathrm{dl}, 97.4 \pm 1.470$ $\mathrm{mg} / \mathrm{dl}, 99.8 \pm 1.625 \mathrm{mg} / \mathrm{dl}, 91.6 \pm 1.503 \mathrm{mg} / \mathrm{dl}, 100.6 \pm 0.95$ $\mathrm{mg} / \mathrm{dl}$ and $98.0 \pm 1.125 \mathrm{mg} / \mathrm{dl}$ on day $0,1 / 2,1,2,4,8,12$ and $24 \mathrm{~h}$ respectively. The above values show that the fasting plasma glucose in the normal group of mice was maintained within the normal range throughout the period of study.

The Glibenclamide $(600 \mu \mathrm{g} / \mathrm{kg})$ treated normal mice show a mean $( \pm$ SEM) fasting plasma glucose of $104.2 \pm 2.835 \mathrm{mg} / \mathrm{dl}$ on the $0 \mathrm{~h}$ which was reduced to $88.0 \pm 2.302 \mathrm{mg} / \mathrm{dl}$ on $1 / 2 \mathrm{~h}, 85.6 \pm 2.713 \mathrm{mg} / \mathrm{dl}$ on $1 \mathrm{~h}$, $82.4 \pm 2.441 \mathrm{mg} / \mathrm{dl}$ on $2 \mathrm{~h}, 77.8 \pm 2.782 \mathrm{mg} / \mathrm{dl}$ on $4 \mathrm{~h}$, $72.4 \pm 2.542 \mathrm{mg} / \mathrm{dl}$ on $8 \mathrm{~h}, 75.16 \pm 2.212 \mathrm{mg} / \mathrm{dl}$ on $12 \mathrm{~h}$ and $86.83 \pm 3.554 \mathrm{mg} / \mathrm{dl}$ on $24 \mathrm{~h}$. These changes in fasting plasma glucose values illustrate that the normal mice treated with Glibenclamide show a progressive and significant $(\mathrm{p}<0.01)$ reduction in fasting plasma glucose, during the $24 \mathrm{~h}$ on single dose treatment period in comparison to the normal group of mice. This indicates that the Glibenclamide treatment of normal mice is able to reduce the fasting plasma glucose levels below the normal up to $8 \mathrm{~h}$ but it further increase on $12 \mathrm{~h}$ and $24 \mathrm{~h}$ of the study period.

The herbal preparation-1 $(1.0 \mathrm{ml} / \mathrm{kg})$ treated normal mice show a mean $( \pm$ SEM $)$ fasting plasma glucose of $100.8 \pm 1.114 \mathrm{mg} / \mathrm{dl}$ on the $0 \mathrm{~h}$ which was reduced to $97.2 \pm 1.319 \mathrm{mg} / \mathrm{dl}$ on $1 / 2 \mathrm{~h}, 93.2 \pm 1.114 \mathrm{mg} / \mathrm{dl}$ on $1 \mathrm{~h}$, $90.4 \pm 1.166 \mathrm{mg} / \mathrm{dl}$ on $2 \mathrm{~h}, 87.0 \pm 1.265 \mathrm{mg} / \mathrm{dl}$ on $4 \mathrm{~h}$, $81.0 \pm 1.342 \mathrm{mg} / \mathrm{dl}$ on $8 \mathrm{~h}, 83.83 \pm 1.108 \mathrm{mg} / \mathrm{dl}$ on $12 \mathrm{~h}$ and $86.33 \pm 1.687$ on $24 \mathrm{~h}$. These changes in fasting plasma glucose values illustrate that the normal mice treated with $\mathrm{PH}-1$ show a progressive and significant $(\mathrm{p}<0.01)$ reduction in fasting plasma glucose, during the $24 \mathrm{~h}$ on single dose treatment period in comparison to the normal group of mice. This indicates that the $\mathrm{PH}-1$ treatment of normal mice is able to reduce the fasting plasma glucose levels below the normal up to $8 \mathrm{~h}$ but it further increase on $12 \mathrm{~h}$ and $24 \mathrm{~h}$ of the study period.

The PH-1 $(2.0 \mathrm{ml} / \mathrm{kg})$ treated normal mice show a mean $( \pm$ SEM) fasting plasma glucose of $99.6 \pm 1.369 \mathrm{mg} / \mathrm{dl}$ on the $0 \mathrm{~h}$ which was increased to $100.2 \pm 0.8602 \mathrm{mg} / \mathrm{dl}$ on $1 / 2 \mathrm{~h}$, and later reduced to $88.2 \pm 1.562 \mathrm{mg} / \mathrm{dl}$ on $1 \mathrm{~h}$, $81.4 \pm 1.860 \mathrm{mg} / \mathrm{dl}$ on $2 \mathrm{~h}, 75.6 \pm 2.561 \mathrm{mg} / \mathrm{dl}$ on $4 \mathrm{~h}$, $69.4 \pm 2.441 \mathrm{mg} / \mathrm{dl}$ on $8 \mathrm{~h}, 88.0 \pm 1.581 \mathrm{mg} / \mathrm{dl}$ on $12 \mathrm{~h}$ and $91.8 \pm 0.7348 \mathrm{mg} / \mathrm{dl}$ on $24 \mathrm{~h}$. These changes in fasting plasma glucose values illustrate that the normal mice treated with $\mathrm{PH}-1$ show a progressive and significant $(p<0.01)$ reduction in fasting plasma glucose, during the $24 \mathrm{~h}$ on single dose treatment period in comparison to the normal group of mice. This indicates that the PH-1 treatment of normal mice is able to reduce the fasting plasma glucose levels below the normal up to $8 \mathrm{~h}$ but it further increase on $12 \mathrm{~h}$ and $24 \mathrm{~h}$ of the study period.

The fasting plasma glucose of the different groups of diabetic animals during the period of study is given in table No 7 and presented in graph 3, which shows that the mean fasting plasma glucose $( \pm$ SEM) in the diabetic control group of mice was found to be $270.6 \pm 3.140$ $\mathrm{mg} / \mathrm{dl}, \quad 270.6 \pm 3.140 \mathrm{mg} / \mathrm{dl}, \quad 270.6 \pm 3.140 \mathrm{mg} / \mathrm{dl}$, $266.8 \pm 2.905 \mathrm{mg} / \mathrm{dl}, 269.2 \pm 2.653 \mathrm{mg} / \mathrm{dl}$ and $261.4 \pm 5.683$ $\mathrm{mg} / \mathrm{dl}$ on day 0 , day 1 , day 3 , day 7 , day 15 and day 30 respectively. These elevated fasting plasma glucose levels were found to have been maintained throughout the 30 days of treatment period indicating that the mice are rendered diabetic.

The Glibenclamide $(600 \mu \mathrm{g} / \mathrm{kg})$ treated diabetic mice show a mean ( \pm SEM) fasting plasma glucose of $289.4 \pm 1.691 \mathrm{mg} / \mathrm{dl}$ on day $0,269.8 \pm 3.497 \mathrm{mg} / \mathrm{dl}$ on 1 day, $227.0 \pm 1.378 \mathrm{mg} / \mathrm{dl}$ on 3 day, $212.8 \pm 1.020 \mathrm{mg} / \mathrm{dl}$ on 7 day which was reduced to $178.0 \pm 1.000 \mathrm{mg} / \mathrm{dl}$ on day 15 which reduced further to132.6 $\pm 1.691 \mathrm{mg} / \mathrm{dl}$ on day 30. These changes in fasting plasma glucose values illustrate that the diabetic mice treated with Glibenclamide show a progressive and significant $(p<0.01)$ reduction in fasting plasma glucose, during the four weeks of treatment period in comparison to the diabetic group of mice. This indicates that the Glibenclamide treatment of diabetic mice is able to bring back the fasting plasma glucose levels nearer to normal range in the four weeks of study period.

The PH-1 $(1.0 \mathrm{ml} / \mathrm{kg})$ treated diabetic mice show mean ( \pm SEM) fasting plasma glucose of $272.2 \pm 2.223 \mathrm{mg} / \mathrm{dl}$ on day $0,267.2 \pm 2.223 \mathrm{mg} / \mathrm{dl}$ on 1 day, $256.8 \pm 2.154$ $\mathrm{mg} / \mathrm{dl}$ on 3 day, $238.8 \pm 2.059 \mathrm{mg} / \mathrm{dl}$ on 7 day which was found to have been reduced $212.4 \pm 1.661 \mathrm{mg} / \mathrm{dl}$ on day 15 and $202.2 \pm 1.655 \mathrm{mg} / \mathrm{dl}$ on day 30 . These changes in fasting plasma glucose values illustrate that the diabetic mice treated with $\mathrm{PH}-1(1.0 \mathrm{ml} / \mathrm{kg})$ show a progressive and significant $(\mathrm{p}<0.01)$ reduction in fasting plasma glucose during the 30 days of treatment period in comparison to the diabetic group of mice.

The PH-1 $(2.0 \mathrm{ml} / \mathrm{kg})$ treated diabetic mice shows mean ( \pm SEM) fasting plasma glucose of $279.4 \pm 3.696 \mathrm{mg} / \mathrm{dl}$ on day $0,269.2 \pm 3.652 \mathrm{mg} / \mathrm{dl}$ on day $1,247.4 \pm 3.076$ $\mathrm{mg} / \mathrm{dl}$ on day $3,221.2 \pm 2.577 \mathrm{mg} / \mathrm{dl}$ on day 7 which was reduced to $199.6 \pm 2.943 \mathrm{mg} / \mathrm{dl}$ on day 15 which reduced further to $180.4 \pm 2.619 \mathrm{mg} / \mathrm{dl}$ on day 30 . These changes in fasting plasma glucose illustrate that the diabetic mice treated with $\mathrm{PH}-1(2.0 \mathrm{ml} / \mathrm{kg})$ show a progressive and significant $(\mathrm{p}<0.01)$ reduction in fasting plasma glucose during the 30 days of treatment period in comparison to diabetic group of mice. The above observations show that the treatment of diabetic mice with $\mathrm{PH}-1$ reduces the fasting plasma glucose of diabetic mice at all the tested dose levels, but the high dose of PH-1 (i.e. $2.0 \mathrm{ml} / \mathrm{kg}$ of $\mathrm{PH}-1)$ was able to reduce fasting plasma glucose which was comparable with the reduction caused by 
Glibenclamide treatment during the 30 days of treatment.

The PH-2 $(1.0 \mathrm{ml} / \mathrm{kg})$ treated diabetic mice shows mean ( \pm SEM) fasting plasma glucose of $274.2 \pm 3.625 \mathrm{mg} / \mathrm{dl}$ on day $0,267.0 \pm 3.271 \mathrm{mg} / \mathrm{dl}$ on 1 day, $224.0 \pm 3.317$ $\mathrm{mg} / \mathrm{dl}$ on 3 day, $205.0 \pm 2.608 \mathrm{mg} / \mathrm{dl}$ on 7 day which was reduced to $180.6 \pm 1.913 \mathrm{mg} / \mathrm{dl}$ on day 15 which reduced further to117.6 $\pm 1.887 \mathrm{mg} / \mathrm{dl}$ on day 30 . These changes in fasting serum glucose illustrate that the diabetic mice treated with $\mathrm{PH}-2(1.0 \mathrm{ml} / \mathrm{kg})$ show a progressive and significant $(\mathrm{p}<0.01)$ reduction in fasting plasma glucose during the 30 days of treatment period in comparison to diabetic group of mice.

The PH-2 $(2.0 \mathrm{ml} / \mathrm{kg})$ treated diabetic mice shows mean ( \pm SEM) fasting plasma glucose of $277.0 \pm 3.536 \mathrm{mg} / \mathrm{dl}$ on day $0,260.8 \pm 1.744 \mathrm{mg} / \mathrm{dl}$ on 1 day, $217.6 \pm 1.208$ $\mathrm{mg} / \mathrm{dl}$ on 3 day, $182.8 \pm 1.393 \mathrm{mg} / \mathrm{dl}$ on 7 day which was found to have been reduced $161.4 \pm 1.990 \mathrm{mg} / \mathrm{dl}$ on day 15 and $137.2 \pm 2.775 \mathrm{mg} / \mathrm{dl}$ on day 30 . These changes in fasting plasma glucose illustrate that the diabetic mice treated with $\mathrm{PH}-2(2.0 \mathrm{ml} / \mathrm{kg})$ show a progressive and significant $(\mathrm{p}<0.01)$ reduction in fasting plasma glucose during the 30 days of treatment period in comparison to diabetic group of mice. The above observations show that the treatment of diabetic mice with $\mathrm{PH}-2$ reduces the fasting plasma glucose of diabetic mice at all the tested dose levels, but the high dose of PH-1 (i.e. $2.0 \mathrm{ml} / \mathrm{kg}$ of $\mathrm{PH}-2$ ) was able to reduce fasting plasma glucose which was comparable with the reduction caused by Glibenclamide treatment during the 30 days of treatment.
The PH-3 $(1.0 \mathrm{ml} / \mathrm{kg})$ treated diabetic mice show mean ( \pm SEM) fasting plasma glucose of $272.0 \pm 3.406 \mathrm{mg} / \mathrm{dl}$ on day $0,257.0 \pm 3.114 \mathrm{mg} / \mathrm{dl}$ on 1 day, $216.8 \pm 2.888$ $\mathrm{mg} / \mathrm{dl}$ on 3 day, $211.4 \pm 2.337 \mathrm{mg} / \mathrm{dl}$ on 7 day which was found to have been reduced $178.6 \pm 2.522 \mathrm{mg} / \mathrm{dl}$ on day 15 and $137.0 \pm 2.775 \mathrm{mg} / \mathrm{dl}$ on day 30 . These changes in fasting plasma glucose values illustrate that the diabetic mice treated with $\mathrm{PH}-3(1.0 \mathrm{ml} / \mathrm{kg})$ show a progressive and significant $(\mathrm{p}<0.01)$ reduction in fasting plasma glucose during the 30 days of treatment period in comparison to the diabetic group of mice.

The PH-3 (2.0 ml $/ \mathrm{kg})$ treated diabetic mice shows mean $( \pm$ SEM) fasting plasma glucose of $271.6 \pm 4.13 \mathrm{mg} / \mathrm{dl}$ on day $0,253.8 \pm 3.813 \mathrm{mg} / \mathrm{dl}$ on 1 day, $202.0 \pm 3.27 \mathrm{mg} / \mathrm{dl}$ on 3 day, $175.8 \pm 2.615 \mathrm{mg} / \mathrm{dl}$ on 7 day which was found to have been reduced $158.4 \pm 2.839 \mathrm{mg} / \mathrm{dl}$ on day 15 and $132.6 \pm 1.806 \mathrm{mg} / \mathrm{dl}$ on day 30 . These changes in fasting plasma glucose illustrate that the diabetic mice treated with PH-3 $(2.0 \mathrm{ml} / \mathrm{kg})$ show a progressive and significant $(\mathrm{p}<0.01)$ reduction in fasting plasma glucose during the 30 days of treatment period in comparison to diabetic group of mice. The above observations show that the treatment of diabetic mice with $\mathrm{PH}-3$ reduces the fasting plasma glucose of diabetic mice at all the tested dose levels, but the high dose of PH-3 (i.e. $2.0 \mathrm{ml} / \mathrm{kg}$ of $\mathrm{PH}-1)$ was able to reduce fasting plasma glucose which was comparable with the reduction caused by Glibenclamide treatment during the 30 days of treatment.

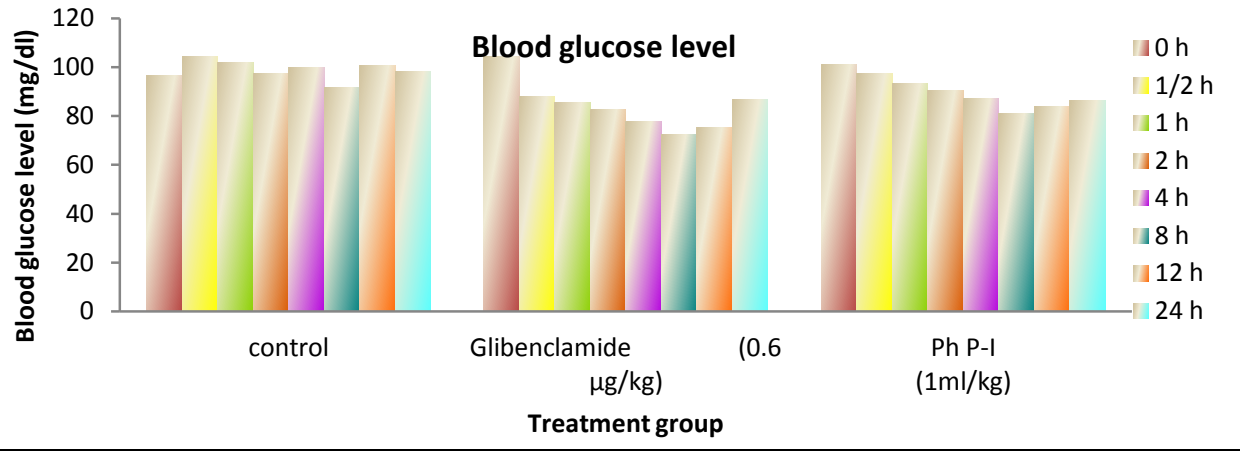

Graph 1: Effect of PH-1 (1 ml/kg) on fasting blood plasma glucose levels after oral administration in normal mice

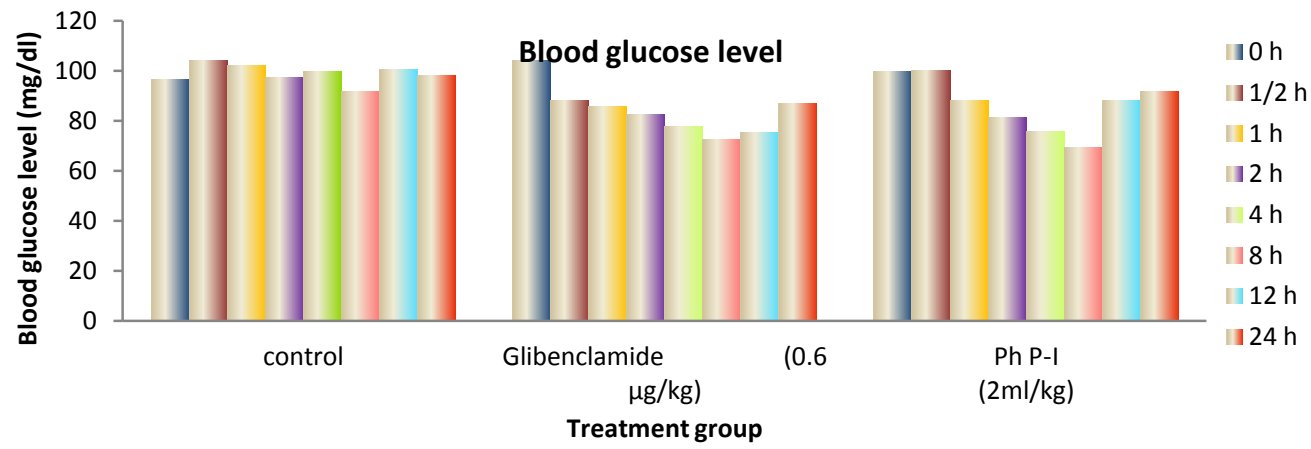

Graph 2: Effect of PH-1 (2 ml/kg) on fasting blood plasma glucose levels after oral administration in normal mice 


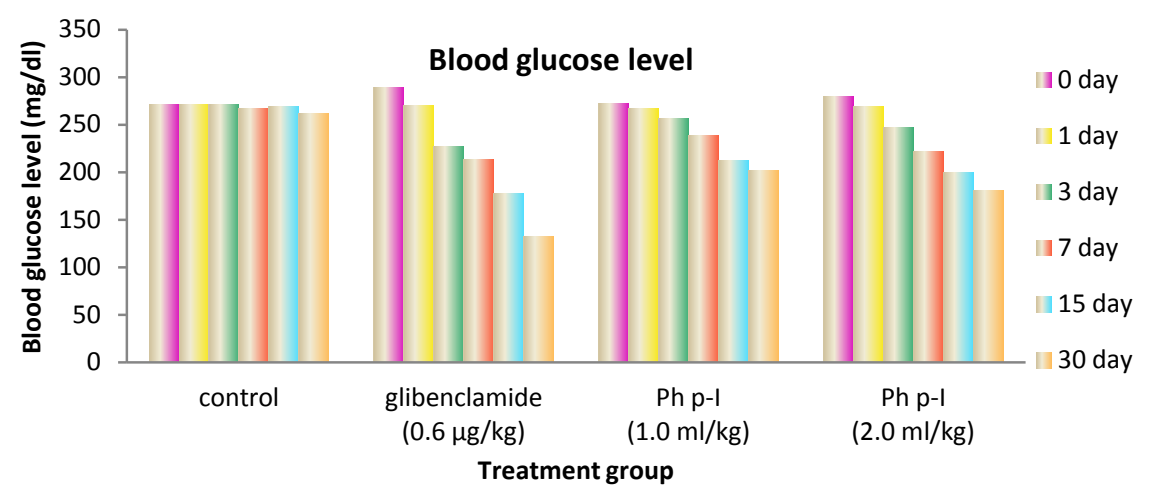

Graph 3: Effect of PH-1 on fasting blood plasma glucose levels after oral administration in alloxan-induced mice

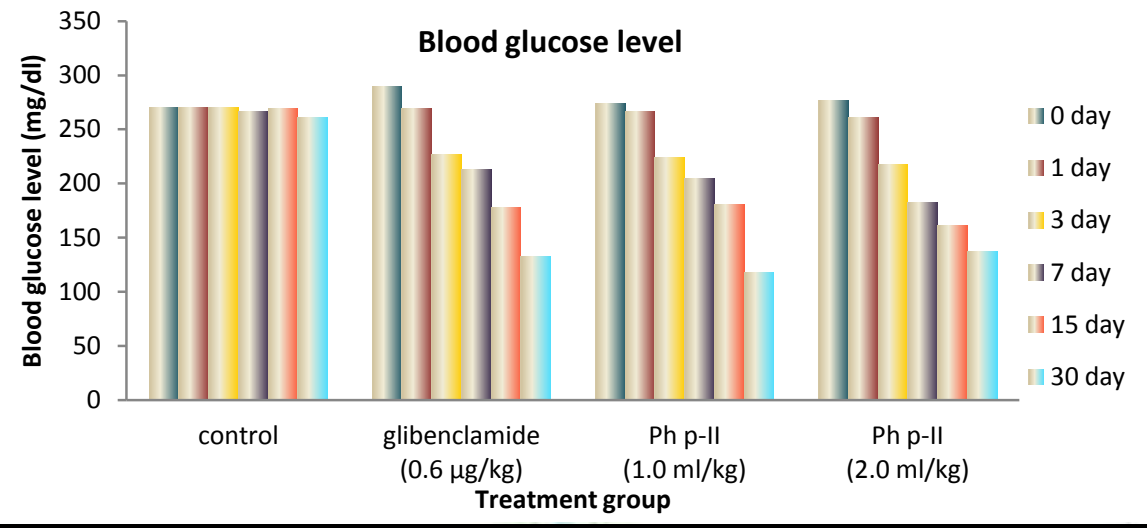

Graph 4: Effect of PH-2 on fasting blood plasma glucose levels after oral administration in alloxan-induced mice

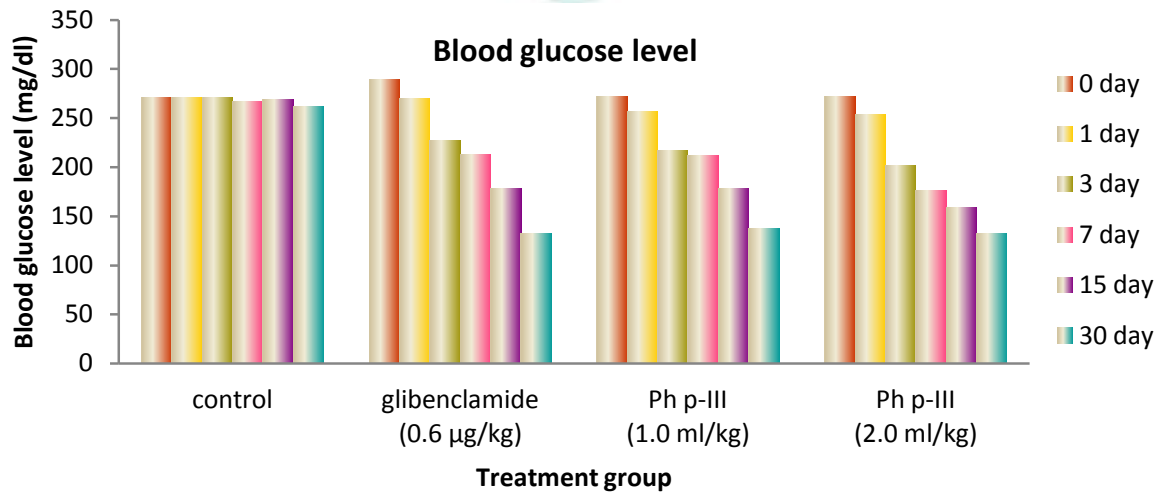

Graph 5: Effect of PH-3 on fasting blood plasma glucose levels after oral administration in alloxan-induced mice

\section{DISCUSSION}

Diabetes mellitus is possibly the world's largest growing metabolic disease, and the knowledge on the heterogeneity of this order is advanced, the need for more appropriate therapy increases. Traditional plant medicines are used throughout the world for the range of diabetic complications as an alternative for conventional hypoglycaemic agents because hypoglycaemic or antidiabetic drugs in NIDDM or Insulin in IDDM have a limited role to play. Risk of drug tolerance is high with oral hypoglycaemic agents, thereby causing a raise in dosage or a change of drug. Ayurvedic medicines may help as "potentiators" for these drugs or play a supportive role in regulating the dosage of hypoglycaemics and maintain the quality of the diabetic life.

In the indigenous Indian system of medicine (Ayurveda) a mention was made on good number of plants for the cure of diabetes but the bioreactivity of single plant preparation is disappointing and most of these remedies 
have moderate potency as well as toxicity thus are not fast acting nor overtly dangerous where as in the Polyherbal preparation forms they are likely to contain several bioreactive components which can act together and elicit additive or synergistic effects which shows optimal therapeutics response that are not apparent when the bioreactive compounds are used independently. Various herbal formulations such as diamed, coagent $\mathrm{db}$, hyponidd, and SMK001 are reported in literature as an antidiabetic formulation while we have made an attempt to use three different plants products in our study viz. wheat germ oil, fresh juice of Coriandrum sativum and Aloe vera to prepare Polyherbal preparation.

In the present study we have found that Glibenclamide $(600 \mu \mathrm{g} / \mathrm{kg})$ treated normal group of mice showed significant $(\mathrm{P}<0.001)$ and progressive reduction in fasting plasma glucose levels during the period of study when compared with the normal untreated. We have also observed that $\mathrm{PH}-1$ treated normal group of mice produce a progressive and significant reduction in fasting plasma glucose level during the period of study when compared with normal untreated mice at all the selected dose levels i.e. at $1.0 \mathrm{ml} / \mathrm{kg}$ and $2.0 \mathrm{ml} / \mathrm{kg}$ but the higher dose $(2.0 \mathrm{ml} / \mathrm{kg})$ have shown more constituent results throughout the study period.

In the study the group of diabetic mice showed elevated fasting plasma glucose levels. This observation suggests that single i.p infection of alloxan $(150 \mathrm{mg} / \mathrm{kg})$ produced a reproducible and consistent diabetes mellitus and appears to be a suitable model of diabetes in our laboratory conditions.

The Glibenclamide $(600 \mu \mathrm{g} / \mathrm{kg})$ treated diabetic group of mice showed significant $(\mathrm{P}<0.001)$ and progressive reduction in fasting plasma glucose levels during the 30 days of study period when compared with the diabetic group of mice. In agreement with the present results, several studies have shown anti-diabetic activity upon Glibenclamide treatment. The PH-1, 2 and 3 treated groups of mice shown progressive and significant $(\mathrm{P}<0.001)$ reduction in fasting plasma glucose of diabetic mice when compared with untreated diabetic mice at all selected dose levels $(1.0 \mathrm{ml} / \mathrm{kg}$ and $2.0 \mathrm{ml} / \mathrm{kg})$ but the higher dose $2.0 \mathrm{ml} / \mathrm{kg}$ have shown more consistent results through the 30 days period of study.

In the present study it can be postulated that PH-1 significantly reduce the normal blood glucose level and $\mathrm{PH}-1,2$ and 3 significantly reduce the elevated blood glucose level in diabetic mice. This indicated possible antidiabetic effect of Polyherbal preparation.

Experimental diabetes is suggested to result from Alloxan, a $\beta$-cytotoxin, a broad spectrum antibiotic has been widely used for inducing the diabetes mellitus in variety of animals. Following its administration, alloxan is concentrated in the islets it is reduced to dialuric acid. This acid is unstable in aqueous solutions and undergoes oxidation back to alloxan, accompanied by generation of $\mathrm{O}_{2}^{-}$, hydrogen peroxide and hydroxyl radicals by Fenton

ISSN: 2250-1177 [94] type reaction ${ }^{137}$ the islet cells have low concentrations of super oxide dismutase (SOD), catalase and glutathione peroxidase it causes a massive destruction of $\beta$-cells of islets of langerhans by accumulation of cytotoxic free radicals resulting in reduced synthesis and release of insulin which paves the ways for the decreased utilization of glucose by the tissues and induce experimental diabetes mellitus. It is well established that sulphonylureas produce hypoglycemia by increasing the secretion of insulin from pancreas and these compounds are active in mild alloxan-induced diabetes whereas they are inactive in intense alloxan diabetes (nearly all $\beta$-cells have been destroyed). Since our results showed that Glibenclamide reduced blood glucose levels in hyperglycemic animals, the state of diabetes is not severe. Alloxan-treated animals receiving the herbal preparation showed reduction of blood glucose levels in comparison to control and this could be due to the possibility that some $\beta$-cells are still surviving to act upon by herbal preparation to exert its insulin releasing effect. Moreover, like sulphonylureas oral administration of herbal preparation produced hypoglycemia in normal animals. This suggests that the mode of action of the active ingredients of herbal preparation is probably mediated by an enhanced secretion of insulin, like sulphonylureas.

The possibility of antidiabetic effect of herbal preparation may be due to the effect of active constituents of different plants, viz, vitamins such vit $C$, minerals such as chromium, manganese, magnesium, zinc and hydro-soluble fiber glucomannan from Aloe vera, vitamin E (tocophherols) from wheat germ oil, and vitamin such as vit $\mathrm{A}$ from Coriandrum sativum.

Ascorbic acid is a reducing agent and can reduce in cells by reaction with glutathione, which can be catalyzed by protein disulfide isomerase and glutaredoxins and thereby neutralize reactive oxygen species such as hydrogen peroxide which is known to mediate the glycation-dependent degradation of several proteins and is widely involved in the damage of various $\beta$-cells and decreasing the $\beta$-cell mass in type- 2 diabetes however, it can also reduce metal ions which leads to the generation of free radicals through the Fenton reaction.

$$
\begin{gathered}
2 \mathrm{Fe} 3++ \text { Ascorbate } \rightarrow 2 \mathrm{Fe} 2++ \text { Dehydroascorbate } \\
2 \mathrm{Fe} 2++2 \mathrm{H} 2 \mathrm{O} 2 \rightarrow 2 \mathrm{Fe} 3++2 \mathrm{OH}^{\cdot}+2 \mathrm{OH}^{-}
\end{gathered}
$$

Magnesium is co-factor in glucose oxidation, modulates glucose transport across cell membranes. May increase insulin secretion and/or improve insulin sensitivity/peripheral glucose uptake where as glucomannan (hydrosoluble fiber) delaying glucose absorption.

Manganese, zinc and iron are co-factor for superoxide dismutase (SODs) that catalyse the breakdown of the superoxide anion into oxygen and hydrogen peroxide which further reduce to give water and protect $\beta$-cells from the toxic effects of reactive oxygen species.

CODEN (USA): JDDTAO 
Vitamin E is lipophilic and inhibits lipid peroxidationwhich occurs in the plasma membrane and damage membrane structure and permeability, scavenging lipid peroxyl radicals to yield lipid peroxides and the tocophroxyl radicals and protects membrane from oxidation. In other words inhibition of lipid peroxidation by antioxidants vit $\mathrm{E}$ improves $\beta$-cells function which might influence protein glycation, lipid oxidation, and insulin secretion/sensitivity. It may also affect nonoxidative glucose metabolism. Besides these active chemical constituents of different plants Polyherbal preparation also possesses vit $A$, vit $B_{12}$, digestive enzymes such as amylase and lipase that can offset the toll blood glucose level.

Therefore, Polyherbal preparation is potent in preserving $\beta$-cell function in diabetes by scavenging free radicals liberated by alloxan in diabetic rats and also regulate key reactions involves in turn on and turn off insulin action as well as in glucose utilization. On the basis of above results, it could be concluded that Polyherbal preparation, a combination of three herbal plants exert a significant antidiabetic effect. This could be due to different types of active principles, each with a single or a diverse range of biological activities, which serves as a good adjuvant in the present armamentarium of antidiabetic drug.

\section{CONCLUSION}

The present study on the PH-1, 2 and 3 formulated from three different plants i.e. Wheat germ oil, fresh juice of Coriandrum sativum and Aloe vera gel in three different

\section{REFERENCES}

1. Kaur M, Bhatia A, Sethi D, Kaur G, Vig K, Hypoglycemic potential of probiotic dna loaded chitosan nanoparticles: an in vivo study, Journal of Drug Delivery and Therapeutics. 2017; 7(2):70-76. DOI: http://dx.doi.org/10.22270/jddt.v7i2.1405

2. Kaveeshwar SA, Cornwall J. The current state of diabetes mellitus in India. Australas Med J. 2014; 7(1):45-48.

3. Ryan G, Briscoe TA, Lynette L. Review of pramlintide as adjunctive therapy in treatment of type 1 and type 2 diabetes. Drug Des Devel Ther. 2009; 2:203-214.

4. World Health Organization, "second report of the WHO Expert committee on diabetes mellitus", Geneva, Technical Report Series; 1980; 646-666.

5. Swarnkar R, Kaushal C, Jain SK, Hypoglycaemic activity of Centratherum anthelminticu in experimental animals, Journal of Drug Delivery and Therapeutics. 2017; 7(4):73-77 DOI: http://dx.doi.org/10.22270/jddt.v7i4.1472

6. Bailey CJ, Day C. Traditional plant medicines as treatments for diabetes. Diabetes Care 1989; 12:553-564.

7. Dangre PV, Fating VD, Wakodkar SB, Godbole MD, Development of stevioside loaded pellets for regulating the ratio's were started with an expectation and objective to explore the possibility of the drug to exert antidiabetic effect. In this study, alloxan induced diabetic animals were used. Antidiabetic animals were treated with different doses of PH-1, 2 and 3 to assess the effect of the drugs. After treatment, to analyze the effect of the drug glucose estimation test was performed. The data obtained were satisfactory and conclusive so as and to accomplish our objectives. In conclusion, the present data indicated that the PH-1 i.e. Wheat germ oil, fresh juice of Coriandrum sativum and Aloe vera in the ratio of 1:1:1 showed significant glucose lowering effect in normal mice and PH-1, 2 i.e. Wheat germ oil, fresh juice of Coriandrum sativum and Aloe vera in the ratio of 2:2:1 and PH-3 i.e. Wheat germ oil, fresh juice of Coriandrum sativum and Aloe vera in the ratio of 1:2:2 showed significant glucose lowering effect in alloxan induced diabetic mice. This study suggests that PH-1, 2, and 3 posses antidiabetic activity and is going to be a promising antidiabetic preparation for masses. Exact mechanism underlying this effect is not clear, but apparently may be due to preserving $\beta$-cell function in diabetic mice. Further studies are needed to elucidate the mechanism of action and to know the active principle/s involved in producing the effect. Keeping in view the tremendous pharmacological activities this herbal preparation possess, it may be utilized to alleviate the symptoms of diabetes, however it has to be confirmed by clinical trials before put into the therapy.

Conflict of interest: There is no conflict of interest.

blood glucose level in diabetes: in vivo- in vitro characterization, Journal of Drug Delivery and Therapeutics. 2017; 7(4):59-65 DOI:

http://dx.doi.org/10.22270/jddt.v7i4.1461

8. L. Verma, A. Khatri, B. Kaushik, U.K. Patil, R.S. Pawar, "Antidiabetic activity of Cassia occidentalis (Linn) in normal and alloxan-induced diabetic rats," Indian Journal of Pharmacology, 2010; 42(4):224-228.

9. Manivannan R, Shopna R, Antidiabetic activity of calotropis gigantea white flower extracts in alloxan induced diabetic rats. Journal of Drug Delivery and Therapeutics, 2017; 7(3):106-111. doi:10.22270/jddt.v7i3.1447

10. Gurjar H, Pandey H, Verma A, Irchhaiya R, Singh P, Antidiabetic activity of bauhinia variegata extracts in alloxaninduced diabetic rats. Journal of Drug Delivery and Therapeutics, 2018; 8(1):29-32. doi:10.22270/jddt.v8i1.1548

11. Issa IA, Bule H, "Hypoglycemic Effect of Aqueous and Methanolic Extract of Artemisia afra on Alloxan Induced Diabetic Swiss Albino Mice," Evidence-Based Complementary and Alternative Medicine, pp. 5, 2015. 